\title{
Characteristics of pregnant women with section caesarean delivery at Bali Royal Hospital, Denpasar General Hospital, Indonesia
}

\author{
N W S Wulandari ${ }^{1}$, D A A A S Astini ${ }^{2}$ \\ Medical Faculty and Health Science of Universitas Warmadewa University, Bali, Indonesia ${ }^{1,2}$ \\ \{sukesukaastini@yahoo.com\}
}

\begin{abstract}
Section caesarean is one form of childbirth through surgical procedures. In Indonesia, it is high enough in private hospitals such as the Bali Royal Hospital Denpasar, Bali, Indonesia. It is influenced by several factors such as age, education level, occupation, parity and section caesarean indications. This research aims to determine the characteristics of maternity mothers with section caesarean delivery at the Bali public hospital Royal Hospital Denpasar. This study uses a descriptive cross-sectional design. The variables examined are age, education level, occupation, parity and indication of the delivery of section caesarean. Research samples amounted to 100 samples, selected systematic random sampling from 1004 maternity mothers in the population. The data used is secondary data obtained from a medical record, then analyse descriptively. The results showed that the characteristics of maternity mothers with section caesarean delivery in Bali Royal Hospital Denpasar based on sociodemographic factors, most of which are 20-35 years $(83 \%)$, have a higher education level $(45 \%)$ and worked as a private employee $(52 \%)$. Whereas based on the medical-obstetric factors have mostly had nullipara parity (54\%) and has medical indications (85\%), most of which have a previous section caesarean history of $42.19 \%$. The characteristics of mothers who underwent caesarean section showed a tendency of productive age mothers and high levels of knowledge, in addition to the tendency of pregnancy to be nullipara or having a history of previous sectio and sectio caesarean performed based on medical indications.
\end{abstract}

Keyword : Pregnant, Caesarean, General Hospital.

\section{Introduction}

Childbirth is the process of spending results of conception (fetus and placenta) that had been old enough or able to live outside the uterus; spending through the birth or with other assistance[1]. There are two ways of giving birth, childbirth through the vagina (natural birth) and cesarean delivery or section caesarean i.e. operating actions for removing the baby through the incision on the abdominal wall and uterus wall on condition the uterus intact as well as the weight of the fetus above $500 \mathrm{~g}$ [2]. In developed countries, there is an increase in 
section caesarean due to indications of a shoulder dystocia or if there is a poor progression to childbirth [3].

In some countries of the world, the section caesarean has a significant increase. In Albania it increased from $22.7 \%$ in 2008 to $30 \%$ in 2011 , in Georgia it increased from $24.5 \%$ in 2008 to $34.7 \%$ in 2011, and in Bulgaria increased from $28.4 \%$ in 2008 to $33.1 \%$ in the year 2011[4]. In the past, labor with sectio caesarea is a scary thing because it is very risky to cause death, but with the development of technology in the field of medicine, section caesarean not scary anymore even today birth section caesarean tends to be done without medical indication (on request)[5]. Section caesarean labor numbers increase every year in many countries including Indonesia. In Indonesia, the number of labor section caesarean in government hospital approximately $20-25 \%$ of the total amount of labor, whereas in private hospitals the number is higher, amounting to about $30-80 \%$ of the total number of deliveries [6]. Labor figures section caesarean at the Sanglah Central General Hospital year 2001 of approximately $22.3 \%$ and increased to $34.5 \%$ in 2006 [7].

At Bali Royal Hospital Denpasar, period of January to December 2015, of a total of 1,004 labor, the number of section caesarean is 745 cases $(74.2 \%)$ and the normal delivery amount is 259 cases $(25.7 \%)[8]$. The amount of section caesarean without medical indication (on request) as much as $102(13.69 \%)$ and with medical indications as much as $643(86.3 \%)$. While from July to December 2014 there are 345 section caesarean, and as many as 46 patients $(13.3 \%)$ with the section caesarean due to the non-medical indication (by request)[8]..

Although the technology in medicine has been highly developed, section caesarean risky childbirth complications five times greater than normal childbirth [2]. Babies born through caesarean section delivery, potentially experiencing breathing difficulties after birth (asphyxia) amounted to $57.1 \%[9]$. The complications that arise after a caesarean section is a pain in the area of the incision, probably going decline in functional ability, thrombosis, decreased elasticity of abdominal muscles and the muscles of the pelvic floor, bladder injuries, bleeding, infection, swelling in the lower extremities, and disorders of lactation[10]. The purpose of this research is to know the characteristics of the mothers who have undergone caesarean section delivery in Bali Royal Hospital Denpasar Bali.

\section{Method}

This research was conducted in public hospitals Denpasar Bali Royal Hospital from August to January 2017-2018. The design on this research was descriptive observational research, and research samples are all mothers who had undergone a caesarean section delivery with selected by systematic random sampling in Bali General Hospital Royal Hospital Denpasar year 2016. The variables in this study were age, education level, occupation, parity and indications of labor with the section caesarean. The data used are secondary data, namely the medical records of mothers who gave birth with section caesarean delivery at the Bali Royal Hospital General Hospital Denpasar year 2016. Data was then copied into a secondary data form which was arranged based on the characteristic variables of the mother who gave birth to the section caesarean. Data were analyse descriptively to show frequency distribution using computerized methods and the results were presented in the form of tables or pie charts 


\section{Results And Discussion}

Based on sociodemographic factors, from 100 samples, most mothers are 20-35 years old (83\%), have college education (45\%) and private employees (52\%) (Table 1).

Table 1. Characteristics of maternity with sectio caesarean delivery based on

\begin{tabular}{lc}
\hline \multicolumn{1}{c}{ Determine Factor } & $\mathbf{f}(\mathbf{\%})$ \\
\hline Age & \\
$<20$ & $0(0)$ \\
$20-35$ & $83(83)$ \\
$>35$ & $17(17)$ \\
Level of Education & \\
Primary school & $1(1)$ \\
Junior High School & $0(0)$ \\
Senior High School & $25(25)$ \\
Academy & $29(29)$ \\
College & $45(45)$ \\
Occupation & \\
Housewife & $46(46)$ \\
Goverment employees & $0(0)$ \\
Private employees & $52(52)$ \\
Others & $2(2)$ \\
& \\
\hline
\end{tabular}

The results of this research in line with the research results on the characteristics of mothers who experience childbirth with section caesarean in Moewardi Public Hospital Surakarta with a sample number of 87 mothers, showed that most mothers with childbirth section caesarean aged 20-35 years, as much as $64.4 \%[11]$. Similarly, the results of the study of maternal characteristics with section caesarean at the General Hospital of DR. Pirngadi Medan year 2011-2012 with a sample number of 87 mothers, showing the majority of mothers aged 20-35 years, as much as $78.2 \%[12]$. The results of this research are not in line with the previous opinion, that pregnancy and childbirth at the age above 35 years have a risk of three times greater to do section caesarean section[13]. Similarly, another study on sectio caesarea factor in the Islamic General Hospital YAKSSI Gemolong Sragen with a sample number of 60 mothers, which showed different results, most mothers with caesarean section section aged $\geq$ 35 years $(48.3 \%)[6]$.

It can be explained that the parity of the maternal age in the first time pregnant or maternity is between the age of 20-35 years which is the optimal reproductive age range for a mother to conceive and give birth. In addition, multipara parity is related to older age, increasing maternal parity, hence the distance of pregnancy and childbirth is further away. This is in accordance with the theory, that the distance of pregnancy is too far related to the increasing age of mothers[14]. The results of this research are in line with the research results of factors that contribute to increasing the incidence of Sectio Caesarea at Liun District General Hospital Kendage Tahuna with a sample number of 167 mothers, indicating that the highest frequency is a college, as much as $33.53 \%[13]$. The results of this study are different from previous research on indications analysis in RSUP Dr. Soeradji Tirtonegoro Klaten, which shows that the highest level of respondents education is the level of low education (SDSMP) as much as $60 \%[15]$.

It can be explained that with the younger age of women getting married, the lower the level of education that the woman is reaching, because in young women's marriage tends to 
have to quit school because it has another priority, that is to be responsible as a wife and a prospective mother [16]. The results of this study are in line with the research results in Moewardi District General Hospital Surakarta, which shows that most mothers work (80.5\%) [11]. The results of this study were not in line with the earlier opinion that the mother who did not work had a higher risk for childbirth with section caesarean [9]. Similarly, the study at Dr. Soeradji Tirtonegoro Klaten Hospital showed a different result that most of the respondents were housewives of $76.7 \%[15]$. This is due to the difference in the respondent's characteristics. It can be explained that with the higher level of education that a person has, then the opportunity to get the job will be greater [17]. Based on medico-obstetrics factors, from 100 samples, most mothers are nullipara (54\%) and most with medical indications $(85 \%)$. Based on medical indication, most mothers has history of section caesarean $(28 \%)$ (Table 2 and Figure 1).

Table 2. Characteristics of maternity with sectio caesarean delivery based on medico-obstetric

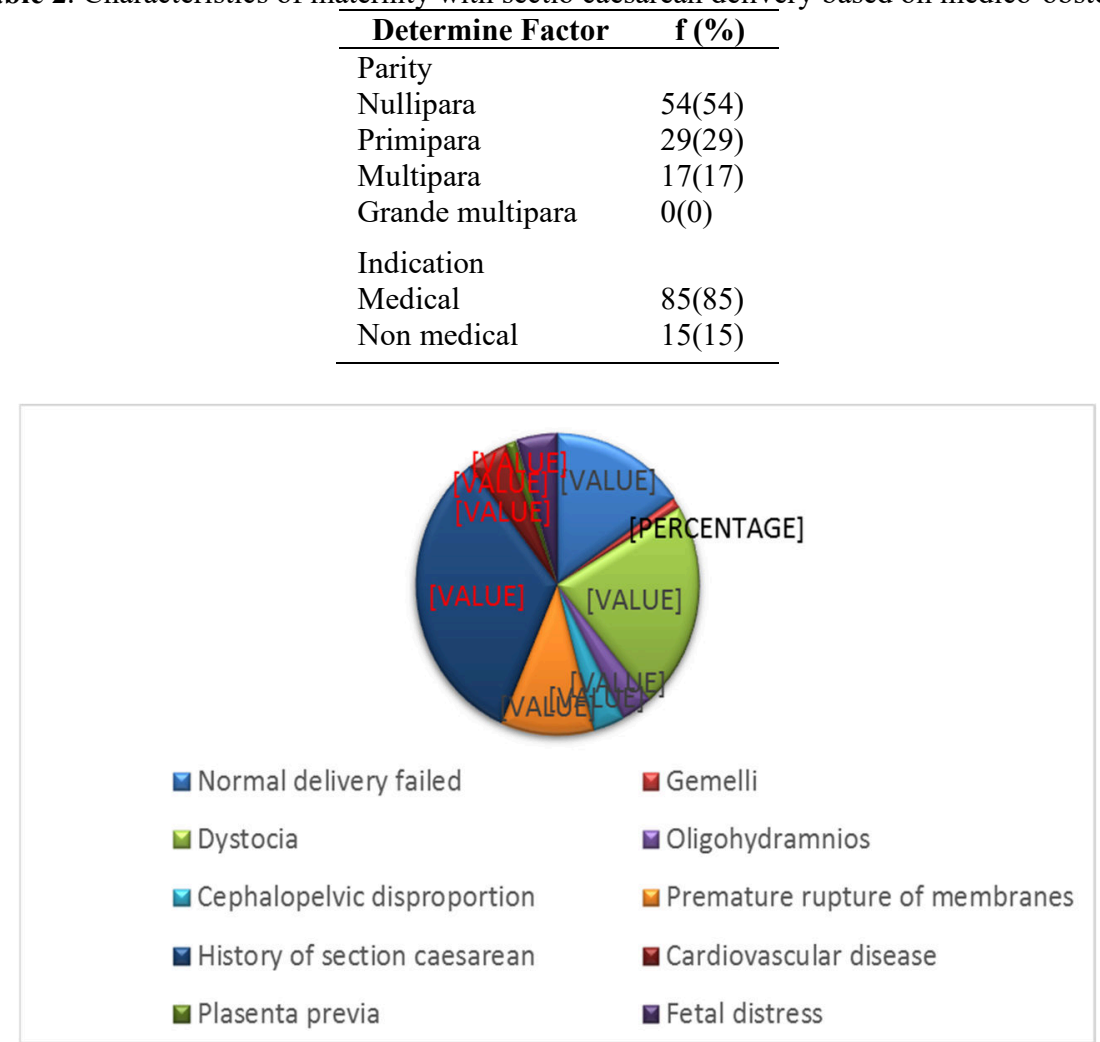

Fig. 1. Medical indication maternity with sectio caesarean delivery

The results of this research in line with the research in Moewardi Public Hospital Surakarta, which shows that the majority of mothers with section caesarean have high risk parity (nullipara, primipara and grande multipara) which is as much as $82.8 \%$ [11]. The results of this research also support the opinion that the first childbirth usually has a relatively high risk to mother and child, but this risk will decrease in second and third parity and will increase again in the fourth parity and beyond[1]. The results of this study differed from previous 
research at the Sidikalang Regional General Hospital year 2007 with a sample number of 258 mothers with section caesarean, which shows that most mothers are multipara as much as $35.3 \%[17]$. The difference in research is caused by different respondents characteristics. It can be explained that women who pursue lower education have a probability of getting married more early than women whose education is higher, because high-educated women tend to postpone marriage until they can complete their education in college, by reason of getting married while taking education will divide their focus[19].

The results of this study were in line with the research at the Sidikalang General Hospital, which showed that most of the mothers with section caesarean had medical indications of 93\%[18]. Similarly, the research in the General Hospital of Dr. Pirngadi Medan, which shows the majority of mothers have medical indications of as much as $90.8 \%$ and most of the medicacal indications are previous section caesarea history with a total of $42.19 \%[12]$.

\section{Conclusions}

Characteristics of maternity mothers with section caesarean delivery at the Bali Royal Hospital Denpasar, shows that most mothers aged 20-35 years, which is as many as 83 people $(83 \%)$, have a higher education level as much as 45 people $(45 \%)$, working as a private employee as many as 52 people (52\%), have Nullipara parity as much as 54 people $(54 \%)$ and has a medical indication of a total of 85 people $(85 \%)$, most of which have a previous section caesarean history of 27 people $(42.19 \%)$.

\section{References}

[1] Sulistyawati A, Nugraheny E. 2010. Buku Ajar Asuhan Kebidanan pada Ibu Bersalin. Jakarta: Salemba Medika

[2] Salfariani I. 2012. Faktor-faktor yang Mempengaruhi Ibu Memilih Persalinan Sectio Caesarea Tanpa Indikasi Medis di Rumah Sakit Umum Bunda Thamrin Medan [skripsi]. Medan (Indonesia): Universitas Sumatera utara

[3] Penn Z. 2001. Indications for caesarean section. Best Practice \& Research Clinical Obstetrics \& Gynaecology. 15(1): 1-15

[4] Mylonas I., Friese K. 2015. Indications for and Risks of Elective Cesarean Section. Dtsch Arztebl Int.112(29-30): 489-495

[5] Dipta TP. 2010. Karakteristik Ibu Bersalin dengan Partus Tak Maju Rawat Inap di RS. Santa Elisabeth Medan Tahun 2005-2009 [skripsi]. Medan (Indonesia): Universitas Sumatera utara

[6] Mulyawati I, Azam M, Ningrum DNA. 2011. Faktor Tindakan Persalinan Operasi Sectio Caesarea. Jurnal Kesehatan Masyarakat: 7; 14-21.Viewed04 December 2016, from: journal.unnes.ac.id/index.php/kemas

[7] Kementerian Kesehatan Republik Indonesia. 2010. Riset Kesehatan Dasar (Riskesdas) 2010. Jakarta: Kementerian Kesehatan Republik Indonesia

[8] Widhi NM. 2016. Faktor yang Mempengaruhi Keputusan Ibu Hamil untuk Memilih Persalinan dengan Metode Sectio Caesarea (Sc) Tanpa Indikasi Medis di RSU Bali Royal Hospital Tahun 2016 [skripsi]. Denpasar (Indonesia): Universitas Udayana

[9] Zainuddin Z, Wilar R, Mantik MFJ. 2013. Hubungan Jenis Persalinan dengan Kejadian Asfiksia Neonatorum di RSUP Prof. DR. Kandou Manado. Jurnal E-Clinic (ECL): 1; 1-7. Viewed 04 December, from: ejournal.unsrat.ac.idPatted S. 2011 
[10] Caesarean Section on Maternal Request (CDMR). Recent research in sciencemand technology: 2; 100-101. Viewed 04 December 2016, from: scienceflora.org/journals/index.php/rrs t/article/view/598

[11] Muhammad R. 2016. Karakteristik Ibu yang Mengalami Persalinan dengan Sectio Caesarea di Rumah Sakit Umum Daerah Moewardi Surakarta Tahun 2014 [skripsi]. Surakarta (Indonesia): Universitas Muhammadiyah Surakarta

[12] Siregar SMF. 2013. Karakteristik Ibu Bersalin dengan Sectio Caesarea di Rumah Sakit Umum Daerah DR. Pirngadi Medan Tahun 2011-201 [skripsi]. Medan (Indonesia): Universitas Sumatera utara

[13] Sumelung V, Kundre R, Karundeng M. 2014. Faktor-faktor yang Berperan Meningkatkan Angka Kejadian Sectio Caesarea di Rumah Sakit Umum Daerah Liun Kendage Tahuna. Ejournal Keperawatan: 2; 1-7. Viewed 04 December 2016, from: ejournal.unsrat.ac.id

[14] Harisah N. 2014. Analisis Faktor yang Memengaruhi Seksio Sesarea Indikasi Non Medis di Rumah Sakit Umum Daerah Teungku Peukan Kabupaten Aceh Barat Daya Tahun 2013 [tesis]. Medan (Indonesia): Universitas Sumatera Utara

[15] Yaeni M. 2013. Analisa Indikasi Dilakukan Persalinan Sectio Caesarea di RSUP dr. Soeradji Tirtonegoro Klaten [skripsi]. Surakarta (Indonesia): Universitas Muhammadiyah Surakarta

[16] Mubasyaroh. 2016. Analisis Faktor Penyebab Pernikahan Dini dan Dampaknya bagi Pelakunya. Yudisa: 7; 385-411. Viewed 19 December 2017, from: Journal.stainkudus.ac.id

[17] Setiawan A, Woyanti N. 2010.Pengaruh Umur, Pendidikan, Pendapatan, Pengalaman Kerja dan Jenis Kelamin terhadap Lama Mencari Kerja bagi Tenaga Kerja Terdidik di Kota Magelang [skripsi]. Semarang (Indonesia): Universitas Diponegoro

[18] Sinaga EMD. 2009. Karakteristik Ibu Yang Mengalami Persalinan Dengan Sectio Caesarea yang Dirawat Inap di Rumah Sakit Umum Daerah Sidikalang Tahun 2007 [skripsi]. Medan (Indonesia): Universitas Sumatera utara

[19] Astusti HD. 2011. Pengaruh Pendidikan Formal terhadap Usia Perempuan pada Pernikahan Pertama [skripsi]. Jakarta (Indonesia): Universitas Islam Negeri Syarif Hidayatullah 